\title{
FROM SPAGHETTI BOWL TO JIGSAW PUZZLE? ADDRESSING THE DISARRAY IN THE WORLD TRADE SYSTEM
}

Jayant Menon

NO. 140

October 2014
ADB WORKING PAPER SERIES ON REGIONAL ECONOMIC INTEGRATION 

ADB Working Paper Series on Regional Economic Integration

\section{From Spaghetti Bowl to Jigsaw Puzzle? Addressing the Disarray in the World Trade System}

Jayant Menon*

No. 140 | October 2014
*Lead Economist, Office of Regional Economic Integration, Asian Development Bank, 6 ADB

Avenue, Mandaluyong City, 1550 Metro Manila,

Philippines.jmenon@adb.org 
The ADB Working Paper Series on Regional Economic Integration focuses on topics relating to regional cooperation and integration in the areas of infrastructure and software, trade and investment, money and finance, and regional public goods. The Series is a quick-disseminating, informal publication that seeks to provide information, generate discussion, and elicit comments. Working papers published under this Series may subsequently be published elsewhere.

Disclaimer:

The views expressed in this paper are those of the author and do not necessarily reflect the views and policies of the Asian Development Bank (ADB) or its Board of Governors or the governments they represent.

ADB does not guarantee the accuracy of the data included in this publication and accepts no responsibility for any consequence of their use.

By making any designation of or reference to a particular territory or geographic area, or by using the term "country" in this document, $A D B$ does not intend to make any judgments as to the legal or other status of any territory or area.

Unless otherwise noted, "\$” refers to US dollars.

(C) 2014 by Asian Development Bank

October 2014

ISSN 2313-5999 (Print), 2313-6006 (e-ISSN)

Publication Stock No. WPS146878-2 
Abstract iv

1. Introduction 1

2. The Regional Jigsaw Puzzle 2

3. The Global Jigsaw Puzzle 7

4. The Way Forward 9

5. Conclusion $\quad 15$

References 16

ADB Working Paper Series on Regional Economic Integration 18

Figures

1. FTAs by Status-Total Asia (cumulative), selected years 2

2. FTAs by Status-ASEAN+6 (cumulative), selected years 3

3. ASEAN+6 Imports from FTA partners as \% of Total Imports, 2011

Tables

1. Bilateral FTAs within ASEAN+6

2. Value of Goods Imports from FTA Partners (\$ million) and Share in Total Imports (\%), 2011

3. Impacts of Alternative Modalities of Liberalization for RCEP Countries (Percentage Deviation from Baseline in 2020) 


\section{Abstract}

The rise of mega-regionals such as the Regional Comprehensive Economic Partnership (RCEP) and the Trans-Pacific Partnership (TPP) suggests that the world trade system is fragmenting to the point it appears more like a jigsaw puzzle than a spaghetti bowl. There are both regional and global jigsaw puzzles to be solved-in that order-to clean up the world trade system. But is this even likely? The difficulties of free trade agreement (FTA) consolidation at the regional level are well known, while piecing together the blocs around the world to form a coherent whole is even more challenging. In this context, a way forward is to return to the most widely used modality of trade liberalization-unilateral actions-but this time involving the multilateralization of preferences rather than unreciprocated reductions in tariff rates. As more and more FTAs are negotiated, preference erosion sets in, reducing the resistance of FTA partners to multilateralization. Multilateralization of preferences may then present a practical way forward in addressing the disarray in the world trade system.

Keywords: multilateralization of preferences, mega-regionals, FTA, TPP, RCEP, reciprocity

JEL Classification: $\mathrm{F}_{13}, \mathrm{~F}_{14}, \mathrm{~F}_{17}$ 


\section{Introduction}

When Jagdish Bhagwati (1991) famously described the maze of overlapping free trade agreements (FTAs) as being akin to a "spaghetti bowl," it spawned a host of gastronomical metaphors, some more bizarre than others. When the epicenter of FTA proliferation switched to Asia in the 2000s, Richard Baldwin (2004) dubbed it the "noodle bowl." When attention shifted to how to rectify the mess and return order to the world trade system, lasagna and even pizza appeared on to the menu (Hamada as quoted in Bhagwati [2008]). Turning spaghetti or noodles into lasagna involves consolidating bilateral FTAs into a regional bloc, while making pizza involves subsequently linking these regional blocs through cross-regional tie-ups, eventually achieving fully multilateral trade. Turning lasagna into pizza is a culinary feat that finds its parallel at the political level in turning the regional blocs into a multilateral one. But both the lasagna-and pizza-making processes are probably better represented by the activity involved in solving different kinds of jigsaw puzzles, as this is what they more closely resemble.

While the recent success in Bali in securing a multilateral agreement on trade facilitation may have resuscitated the World Trade Organization (WTO), it also marked the death knell for the single undertaking. Given that the Doha Round can no longer be concluded as originally intended, both processes - trying to solve the regional and global jigsaw puzzles-are likely to continue. The Association of Southeast Asian Nations (ASEAN) 6 group-consisting of the 10 members of ASEAN plus Australia, the People's Republic of China (PRC), Japan, the Republic of Korea, India, and New Zealand-is attempting to create a consolidated bloc called the Regional Comprehensive Economic Partnership (RCEP) by 2015, in order to supersede the various ASEAN+1 FTAs and other internal bilateral FTAs between individual countries (Menon 2013a). At the same time, the ASEAN countries are aiming to conclude the ASEAN Economic Community (AEC) by the same deadline. Around the world, the United States (US) and the European Union (EU) are pursuing a Trans-Atlantic Trade and Investment Partnership (T-TIP), while the US is also leading the promotion of a Trans-Pacific Partnership (TPP) southward to include seven RCEP members, among others. There is also MERCOSUR, involving Latin and South American countries, the African Economic Community, the Gulf Cooperation Council, and several others.

Can these attempts at regional consolidation succeed and, if they do, will it be possible to link them up to get to global multilateral trade? In other words, will the pieces of the global jigsaw puzzle fall neatly into place, or will the trade landscape disintegrate into fragmented blocs? But before that, the pieces of the puzzle need to be built first, through regional consolidation or cross-regional tie-ups, and this too is like assembling constituent mini-jigsaw puzzles; that is, both regional and global jigsaw puzzles will need to be solved, in that order, if this route is to eventually lead to global free trade. What is the likelihood that such an approach can work? Section 2 of this paper discusses the regional jigsaw puzzles, while Section 3 looks at the challenges associated with solving the global one. A way forward in resolving the trade mess, involving a revival of the unilateral approach as applied to preferences, is proposed in Section 4, while the final section concludes. 


\section{The Regional Jigsaw Puzzle}

Although Asia is a latecomer to preferential trade agreements, ${ }^{1}$ it has been catching up since the 2000 (Figure 1). The past decade has seen more FTAs proposed, negotiated, and ratified in Asia than anywhere else. Within Asia, most of the activity has centered on East Asian countries and ASEAN+6 (Figure 2). There is also a complex web of bilateral FTAs among members of the ASEAN +6 group of countries (Table 1). Therefore, when considering regional puzzles, it is only appropriate that we use RCEP as an example.

Figure 1: FTAs by Status-Total Asia (cumulative), selected years

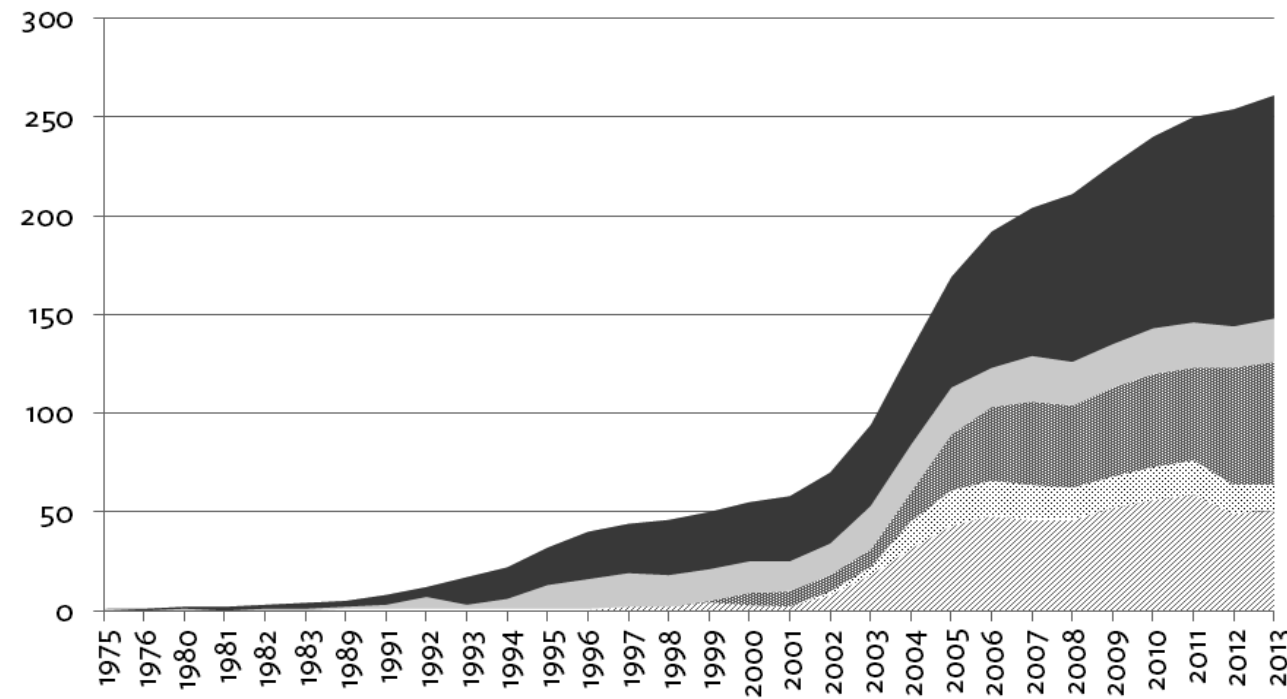
W Proposed
Framework Agreement signed
Negotiations launched
signed but not yet in effect

- Signed and in effect

FTA = free trade agreement

Notes:

1. Proposed: Parties consider an FTA, with the governments or relevant ministries issuing a joint statement on its desirability or establishment of a joint study group or joint task force for the conduct of feasibility studies.

2. Framework Agreement signed: The parties initially negotiate the contents of a framework agreement (FA), which serves as a framework for future negotiations.

3. Negotiations launched: The parties, through the relevant ministries, declare the official launch of negotiations or set the date for such, or start the first round of negotiations.

4. Signed but not yet in effect: Parties sign the agreement after negotiations have been completed. However, the agreement has yet to be implemented.

5. Signed and in effect: Provision of FTA has come into force after legislative or executive ratification.

Source: Asia Regional Integration Center (ARIC) FTA database (as of July 2013).

Japan and the Republic of Korea, for instance, had completely ignored the preferential route until recently. Even though ASEAN is one of the longest-running regional cooperation arrangements among developing countries, it mainly operated as a politico-security pact until the ASEAN Free Trade Agreement (AFTA) in 1992, and even then it has largely remained non-preferential in its implementation of accords by pursuing voluntary multilateralization of preferences (Hill and Menon 2012). 
Figure 2: FTAs by Status-ASEAN+6 (cumulative), selected years

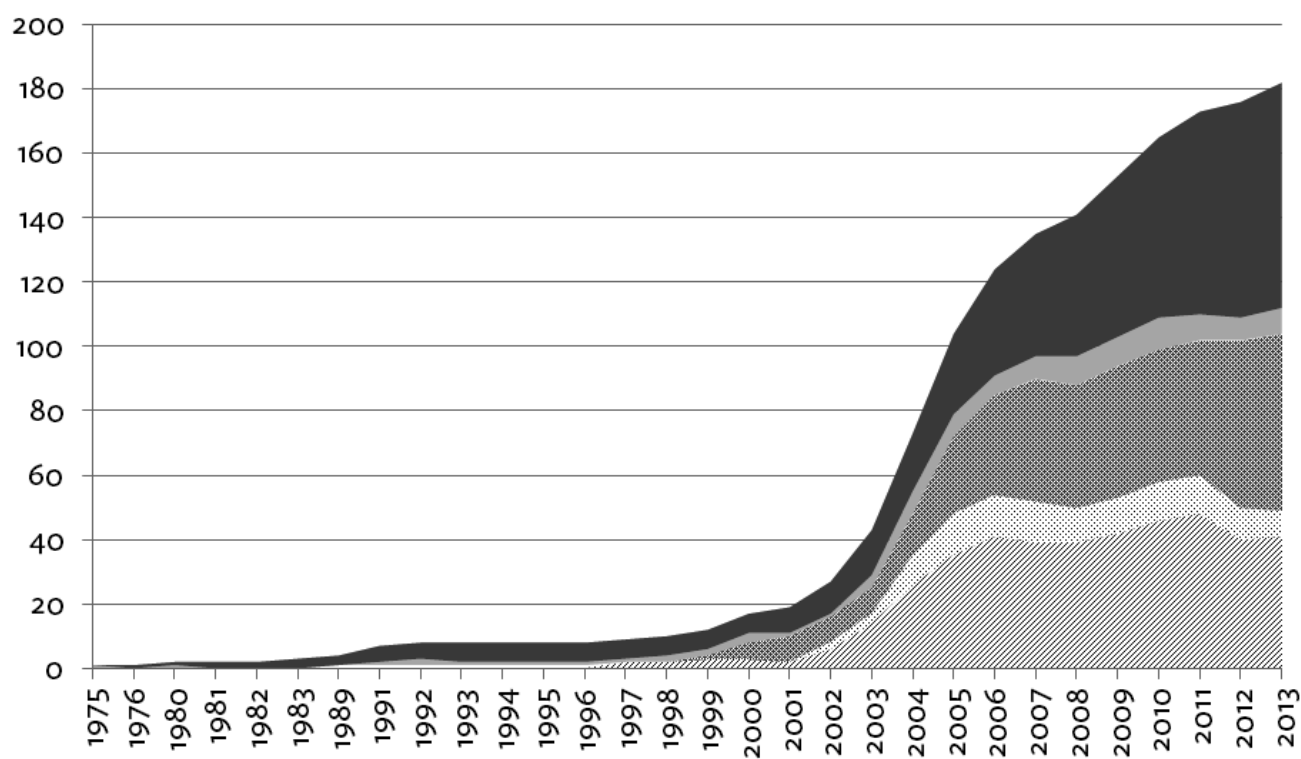

W. Proposed

Negotiations launched

- Signed and in effect
: Framework Agreement signed

Signed but not yet in effect

FTA = free trade agreement.

Notes:

1. Proposed: Parties consider an FTA, with the governments or relevant ministries issuing a joint statement on its desirability or establishment of a joint study group or joint task force for the conduct of feasibility studies.

2. Framework Agreement signed: The parties initially negotiate the contents of a framework agreement (FA), which serves as a framework for future negotiations.

3. Negotiations launched: The parties, through the relevant ministries, declare the official launch of negotiations or set the date for such, or start the first round of negotiations.

4. Signed but not yet in effect: Parties sign the agreement after negotiations have been completed. However, the agreement has yet to be implemented.

5. Signed and in effect: Provision of FTA has come into force after legislative or executive ratification.

Source: Asia Regional Integration Center (ARIC) FTA database (as of July 2013).

Like any jigsaw puzzle, we begin with disarray. But the RCEP puzzle is more than just messythere is no solution because the pieces of the puzzle do not fit. The so-called pieces-the ASEAN+1 and bilateral FTAs - come in different shapes and sizes (both width and breadth) as well as density and vintage. Indeed, they can vary depending on the number of items that are up for negotiated liberalization, and usually just about everything is, including rules of origin (ROOs), and many of these items can vary by product or sector. 
4 | Working Paper Series on Regional Economic Integration No. 140

Table 1: Bilateral FTAs within ASEAN+6

\begin{tabular}{|c|c|c|c|c|}
\hline Economy & Proposed & $\begin{array}{l}\text { FA Signed, Under } \\
\text { Negotiation, or } \\
\text { Signed but not yet } \\
\text { in Effect }\end{array}$ & Signed and in effect & $\begin{array}{l}\text { Total } \\
\text { Number } \\
\text { of FTAs }\end{array}$ \\
\hline Australia (AUS) & & $\begin{array}{l}\text { JPN; IND; INO; } \\
\text { KOR; PRC }\end{array}$ & NZ; MAL; SIN; THA & 9 \\
\hline $\begin{array}{l}\text { Brunei } \\
\text { Darussalam } \\
\text { (BRU) }\end{array}$ & & & JPN & 1 \\
\hline $\begin{array}{l}\text { People's Republic } \\
\text { of China (PRC) }\end{array}$ & IND & AUS, KOR & NZ; SIN; THA & 6 \\
\hline India (IND) & PRC & AUS; INO; NZ; THA & JPN; KOR; MAL; SIN & 9 \\
\hline Indonesia (INO) & & AUS; IND; KOR & $J P N$ & 4 \\
\hline Japan (JPN) & KOR; NZ & AUS & $\begin{array}{l}\text { BRU; IND; INO; MAL; } \\
\text { PHI; SIN; THA; VIE }\end{array}$ & 11 \\
\hline $\begin{array}{l}\text { Korea, Rep. } \\
\text { of (KOR) }\end{array}$ & $\begin{array}{l}\text { JPN; MAL; } \\
\text { THA }\end{array}$ & $\begin{array}{l}\text { AUS; INO; NZ; PRC; } \\
\text { VIE }\end{array}$ & IND; SIN & 10 \\
\hline $\begin{array}{l}\text { Lao People's } \\
\text { Democratic } \\
\text { Republic (LAO) }\end{array}$ & & & THA & 1 \\
\hline Malaysia (MAL) & KOR & & AUS; IND; JPN; NZ & 5 \\
\hline $\begin{array}{l}\text { New Zealand } \\
(\mathrm{NZ})\end{array}$ & JPN & IND; KOR & $\begin{array}{l}\text { AUS; MAL; PRC; SIN; } \\
\text { THA }\end{array}$ & 8 \\
\hline Philippines (PHI) & & & $J P N$ & 1 \\
\hline Singapore (SIN) & & & $\begin{array}{l}\text { AUS; IND; JPN; KOR; } \\
\text { PRC; NZ }\end{array}$ & 6 \\
\hline Thailand (THA) & KOR & IND & $\begin{array}{l}\text { AUS; JPN; LAO; PRC; } \\
\text { NZ }\end{array}$ & 7 \\
\hline Viet Nam (VIE) & & KOR & JPN & 2 \\
\hline $\begin{array}{l}\text { Total \# } \\
\text { of FTAs }\end{array}$ & $5^{*}$ & $12^{*}$ & $23^{*}$ & $40^{*}$ \\
\hline
\end{tabular}

* Unique FTAs (to avoid double counting). Cambodia and Myanmar have no bilateral FTAs.

Source: ARIC FTA database (as of July 2013), Asia Regional Integration Center (ARIC). 
With ROOs, for instance, there are at least 22 different types in operation among the ASEAN+1 FTAs. This total was arrived at after aggregating ROOs that are similar but not the same, and ignoring the fact that some tariff lines have more than one ROO that needs to be met, which could be added to the tally. There are eight different types of ROOs that apply to the electronics chapter alone (HS 85). Even automotive products (HS 87), with just 76 6-digit tariff lines, have six different types of ROOs operating. Only about 30\% of tariff lines across these FTAs share common ROOs (Medalla 2011). There is not only significant variation in ROOs across products within an FTA, but also across FTAs for the same product. The 40 bilateral FTAs (Table 1) between individual members of RCEP further complicate the picture. Take, for instance, the Japan-India FTA, which has 12 types of ROOs, seven of which cannot be found in any of the other ASEAN+1 FTAs. Almost two-thirds of tariff lines use one of these seven new ROOs, and about one-half have to comply with two ROOs: a change in tariff sub-heading and a $40 \%$ domestic content requirement. The ASEAN-India FTA, on the other hand, is the only ASEAN+1 FTA that does not have the de minimis provision, which provides for change-intariff-classification that facilitates product fragmentation trade. The sheer number of ROOs and lack of commonality in their application to tariff lines across FTAs, or variations in the provisions of ROOs across FTAs, raise obvious difficulties in harmonizing and consolidating them.

But consolidate them they must, if RCEP is to eventuate. The question is how and in what form. The only way to make the pieces fit is to reshape them: either to shave them down or to build them up. Shaving down the bits can be thought of as a "race to the bottom," where the lowest common denominator rules, making for an easier fit. Building them up entails the opposite, where laggards reform to meet the standards set by the front-runner(s).

Details remain sparse, but what we do know from RCEP's Guiding Principles is that it will add to, rather than replace, existing ASEAN+1 FTAs, while at the same time introducing "significant improvements" over these agreements. There is, however, an important qualifier in the dreaded flexibility clause: "RCEP will include appropriate forms of flexibility including provision for special and differential treatment, plus additional flexibility to the least-developed ASEAN Member States." Pursuing harmonization while retaining flexibility is likely to produce one of two outcomes. Harmonization implies consensus and a race to the bottom is likely because the country with the lobby that has the most to lose from the dilution of ROOs is also likely to be the most belligerent, and least likely to compromise. Since the gains to a country looking to retain protection usually outweigh the benefits to others from liberalizing $\mathrm{ROO}$ s, the incentive structure would favor the former. ${ }^{2}$ This follows from Baldwin's (2006) asymmetric lobbying theory, which explains why potential losers tend to lobby harder. Alternatively, countries exercising flexibility could result in conservatism-approximating the status quo and preserving the current noodle bowl." These outcomes are more likely than the hoped for raceto-the-top scenario, unless incentives are provided to overcome pressure from the vested interests that lobbied for different ROOs to begin with. The very existence of so many ROOs and exemptions confirms the power of such lobbies. Breaking through these pressures will not

2. It is not uncommon for the main beneficiaries of such liberalization to lie outside the bloc, especially if the bloc is not big enough to include the lowest-cost supplier, but then their interests are not represented and do not factor in the calculus. 
be easy, and will require a stronger commitment to reform from all members, big or small, strong or weak (Menon 2013). The problem is that some countries may not see any carrotand there is no stick. Almost in desperation, some have even identified the flexibility itself as the carrot, highlighting RCEP's commitment not to impose or compel commitments from its members. If this is the carrot, then it cannot be much of one, and it comes at the expense of the stick.

If either a race to the bottom or a minimal change scenario plays out, then RCEP will be largely redundant. Although cumulation rules may expand through increased membership, this usually amounts to little when product fragmentation of trade is significant (Menon 2012). Changing the type of ROO is more important, but also more difficult. The South Asia Free Trade Agreement (SAFTA), a failed attempt at consolidation, illustrates this. Most trade within South Asia continues under more generous bilateral FTAs or under most favored nation (MFN) rates (Weerakoon 2008). Sadly, SAFTA's main contribution has been to add another strand to the global spaghetti bowl.

Will the same fate befall RCEP? Unless there is enough political will to close potential loopholes disguised as flexibility and pursue reforms deeper than those ever before attempted, RCEP's future as a consolidated bloc remains uncertain. RCEP faces many challenges but this is the fundamental one. Previous assessments of challenges facing RCEP have failed to recognize this fundamental constraint, and have focused on side issues ranging from the apparent need to address agriculture more fully to even proposing increasing investment in infrastructure (Das 2012, Kawai and Wignaraja 2013). It is difficult to imagine how a preferential agreement can deal with agricultural liberalization more fully when the greatest distortion in this sector relates to production subsidies, which cannot be removed selectively or preferentially. To suggest that infrastructure investment should be increased in order to make RCEP or any other FTA more effective is to confuse means and ends. Asia may need more investment in infrastructure but this should not be to make a second-best policy appear less so, but to promote growth and development, for its own sake.

We have discussed RCEP in some detail in order to illustrate the difficulties associated with regional consolidation, but the other important mega-regional in the Asia and Pacific region is the proposed TPP agreement. Mega-regionals like the TPP can cut across geographic subregions, and unlike RCEP it is not aimed at consolidation since not all members have bilateral FTAs between them nor are they part of common plurilateral agreements. But where they do exist, there is no intention of preserving any of the bilateral or plurilateral agreements among members. It is clear in its aim to further by creating an agreement so deep that it should neutralize any existing agreements either by matching or superseding them. The TPP's agenda is more wide-ranging and ambitious than Doha. In addition to harmonizing ROOs and the like, just as with solving the regional puzzle, it purports to address areas that have never been successfully dealt with before by any of the countries involved. But prospects for completion are not looking good. The TPP has already missed three deadlines, the latest one being October 2013.

This is not surprising if one looks closely at what is being attempted, and compares it with the Doha experience. Although there are less countries involved in TPP negotiations compared to 
Doha, the difficulties that diversity in positions introduces into the negotiating process is not a linear function of the number of countries involved; that is, moving from more than 150 countries to 12 does not proportionately reduce diversity in negotiating positions. To illustrate the point, there can be as much diversity between two countries as there are among a group of 150 if the two have very different positions on key issues. When a grouping includes countries as varied as Viet Nam, Brunei Darussalam, Peru, and the US, then there is sufficient diversity to complicate negotiations being pursued on a single undertaking basis, especially when the agenda is a highly ambitious one. For these and other reasons, there is also concern that the TPP is degenerating into a series of bilateral deals, with a US-Japan agreement at its core. Given sensitivities across members on different issues, a variety of exemptions in the form of so-called "carve-outs" is anticipated, and can only be accommodated through bilateral arrangements. With renewed uncertainty over the prospects of the Obama Administration securing Trade Negotiating Authority or "fast track" from the US Congress, the future of the TPP remains uncertain since other members may be reluctant to sign up to an agreement when it remains unclear if the key proponent can actually deliver.

In sum, solving the regional jigsaw puzzles is clearly a complicated exercise, and fraught with difficulties. This is true whether it involves consolidating existing agreements, like with RCEP, or not, like the TPP. In both cases, there is a serious risk of the final outcome being a highly diluted version of the ambition set at the very beginning of negotiations. A meaningful RCEP or TPP will require resolve similar to that which gave birth to the EU-an example of successful FTA consolidation, if nothing else. There does not seem to be such political will in Asia at the moment for RCEP. Given that securing trade promotion authority in the US appears increasingly unlikely, the future of the TPP also remains uncertain. Therefore, unless these challenges are overcome soon, RCEP and TPP may be seen as serving the geopolitical interests of a few players, to little economic effect.

\section{The Global Jigsaw Puzzle}

Despite the difficulties associated with solving the regional puzzles, it is still only part of the solution toward addressing the disarray in the world trade system. To illustrate, let us assume that RCEP succeeds in coming up with a consolidated agreement that supersedes its constituent components - that the regional jigsaw puzzled is solved and the resulting image is a better and brighter one than before. Let us also assume that the TPP is concluded as originally intended, as are all the other mega-blocs around the world. If this is the best-case scenario, what does success look like? Not good at all, unfortunately-it would merely substitute the mess at the regional level with one at the global level. We end up with a fragmented world trade system, or one that is carved up into distinct blocs.

Solving the global jigsaw puzzle can be pursued in a number of ways. One often discussed proposal is to try and tie-up the various regional blocs so that they may be linked together, almost seamlessly. Is this likely?

All of the problems associated with solving the regional jigsaw puzzle are also present in solving the global puzzle. Furthermore, there are additional complications that arise. Not only are 
some pieces of the jigsaw puzzle missing (parts of South and Central Asia, the Middle East, and the Pacific island countries are absent); there are also overlapping bits or pieces that are redundant and probably irreconcilable. And unlike with RCEP, for instance, the global puzzle cannot be solved by retaining the regional ones-the intention is for them to disappear. Therefore, the link-ups must go at least as far as, or further than, what exists in their constituent parts for the outcome to approximate multilateral free trade. But then this is akin to concluding Doha, and there is no reason to expect that link-ups of this nature will make the task any easier. While there are cases of successful regional consolidation, such as the EU and the North American Free Trade Agreement (NAFTA), cross-regional link-ups of mega-blocs have no precedent. Needless to say, multiple tie-ups of the mega-blocs, approximating global multilateral free trade, have never been attempted.

Although the example of RCEP highlights the diversity that can exist between FTAs within a regional bloc, the diversity between regional blocs is likely to be as high or higher still. Furthermore, it is unclear how the process of global consolidation of the regional blocs will take place. Should it proceed sequentially, or should there be a kind of single undertaking where the different blocs come together to negotiate a comprehensive deal? If the latter sounds like Doha, then it is because it is strikingly similar in terms of process, and likely to be just as difficult to conclude. A sequential bloc-by-bloc, or bottom-up, approach, building on the open accession clauses of existing agreements, may not be much easier either. Assuming that RCEP can harmonize its services sector liberalization or harmonization of sanitary and phytosanitary (SPS) standards with that of the TTP or T-TIP, for instance, will it be able to also merge them with the South American, or African, blocs, or indeed both? The gulf in the levels of development between these blocs, as well as other forms of diversity, poses obvious difficulties. Furthermore, if the route taken toward liberalizing services, for instance, is through mutual recognition arrangements (MRAs), as is the case with ASEAN, rather than harmonization through regulatory convergence toward a regional standard, then the merging of different blocs is even more difficult. Unless the modality employed for liberalization is conducive to expansion, the much bandied about open accession clauses will mean little in practice, especially when considering that the countries looking to accede would not have had any input into the negotiated outcome, and would have to fully accept whatever has been agreed.

Proponents of FTAs argue that deeper agreements can be achieved more rapidly on difficult issues when there are only a small number of negotiating partners involved, and there is evidence to support this argument. But many advocates fail to explain how this principle works within the context of FTA consolidation, or indeed in terms of inter-regional tie-ups in solving the global puzzle. No one has addressed the issue of how these deeper accords can suddenly be agreed upon by reversing the process and adding more countries, or regions. ${ }^{3}$ The experience with the ASEAN+1 negotiation process is that in all of their FTAs the ASEAN+6 member countries have negotiated different terms from the newer "CLMV" members comprising Cambodia, the Lao People's Democratic Republic, Myanmar, and Viet Nam (Menon and Melendez 2011). In some of these FTAs, such as the ASEAN-India agreement, the

3. If access to a bigger market is the lure, enabling the process of adding more countries without diluting accords, then would not the Doha Round be a better, if not easier, process? It may be better. But we know it is not easier. 
terms vary across almost every member, reflecting the reality that countries always negotiate individually rather than as a group, and a common position is only one of a number of possible outcomes. If this process is replicated when it comes to solving the global puzzle, with individual countries or even coalitions of countries within each region negotiating separately, the process could be an extremely cumbersome and difficult one. Again, the snags with concluding Doha come to mind.

In truth, consolidation at the regional or global level may be just as difficult, if not more so, than starting from scratch, as there are no discrepancies to be resolved or policies to be reversed. Getting a pair of countries to agree on a specific set of terms will not necessarily facilitate similar breakthroughs with third parties. To ignore this is to ignore on-the-ground realities and the political economy of FTA negotiations. Anyone who has looked closely at an FTA will know how difficult the task of enmeshing even two similar agreements can be, let alone many different ones. The experience of the Pacific Basin Initiative, involving four Latin American countries-Chile, Colombia, Mexico, and Peru-confirms the point. After several decades of trying to harmonize their bilateral FTAs to arrive at a consolidated regional one, they finally gave up and decided to start negotiations again almost from scratch, which seemed to work.

\section{The Way Forward}

There is a sense of deja vu about the current state of the world trade system. The last time the world appeared to be disintegrating into regional blocs-with the EU pressing ahead with its "1992 Agenda," the apparent build-up of momentum for an embryonic Asia-Pacific Economic Cooperation (APEC), and NAFTA threatening to spread southward-it helped conclude a difficult multilateral round of negotiations. Hill (1994) described how deteriorating trade relations among key economies helped rather than hindered the move toward concluding the Uruguay Round. There was also growing tension in world trade, exemplified by the deteriorating US-Japan relationship at that time, although the PRC appears to have taken Japan's place today. Many hope that the re-emergence of regionalism and trade friction among major economies will result in history repeating itself by reviving multilateralism. The repeat of history appears less likely now that the single undertaking appears to have been replaced by the cherry-picking process with the passing of the WTO's multilateral agreement on trade facilitation. In any case, the Uruguay Round did not dissolve regionalism around the world and in fact, regionalism continued to grow in its aftermath. Doha could never have addressed the negative consequences of regionalism either. Whatever happens at the multilateral level, there will be a need for regional blocs to address the discrepancies reflecting disparate and independently negotiated outcomes. An obvious and practical solution would be to multilateralize their regionalism by offering their negotiated concessions to nonmembers in a non-discriminatory manner. If all regional blocs can see the benefit of pursuing this course of action, we will have an outcome that is not just as good as that of Doha, but much better.

It could be better than Doha for at least two reasons. First, Doha is, in essence, the world's largest FTA in that concessions are traded reciprocally among members, and non-WTO members - of which there are still about 40-are excluded. Many of these nonmembers are small, poor, fragile or landlocked (or isolated in other ways); face high trade costs; and are 
subject to a host of other vulnerabilities. The benefits from engaging them in greater commercial exchange will be substantial, mostly to them but also for the rest of the world. The multilateralization of preferences to all, and not just the WTO membership, would achieve this. It would also eliminate the need for ROOs. Second, and more important, it will do what Uruguay could not, and Doha cannot, and that is to remove, as opposed to dilute, preference discrepancies and other distortions associated with discriminatory arrangements. The contradictions of the jigsaw puzzle will finally be eliminated and the spaghetti bowl emptied of its hazardous content.

In Asia, for instance, more than three-quarters of imports for all RCEP countries, except for the PRC and Australia, are already covered or are about to be covered by an FTA (Figure 3, Table 2). For ASEAN +6 as a group, more than one-third of imports are already covered by FTAs, with another one-third about to be covered with FTA negotiations ongoing. In this context, there is little point in holding out to negotiate reciprocity with a residual set of countries, usually small in terms of trade volumes, especially when full utilization cannot be assured, but trade diversion and deflection are real risks. When country $X$ has concluded FTAs with most of its major trading partners, preference erosion necessarily sets in, and there is often little, if any, preference advantage between the trading partners in country X's market. The only significant advantage that FTA partners have is over the countries that do not have an FTA with country $X$. When the non-FTA partners as a group do not supply a significant share of country X's imports, there is likely to be much less resistance from FTA partners to the multilateralization of preferences. In other words, the proliferation of FTAs is not only eroding preferences between FTA partners, it will also eventually lead to a situation where the perceived cost (to FTA partners) of multilateralizing preferences (to non-FTA partners) starts to diminish, and particularly in relation to the rising cost (to country $X$ ) of maintaining multiple FTAs and implementing their ROOs.

Figure 3: ASEAN+6 Imports from FTA partners as \% of Total Imports, 2011

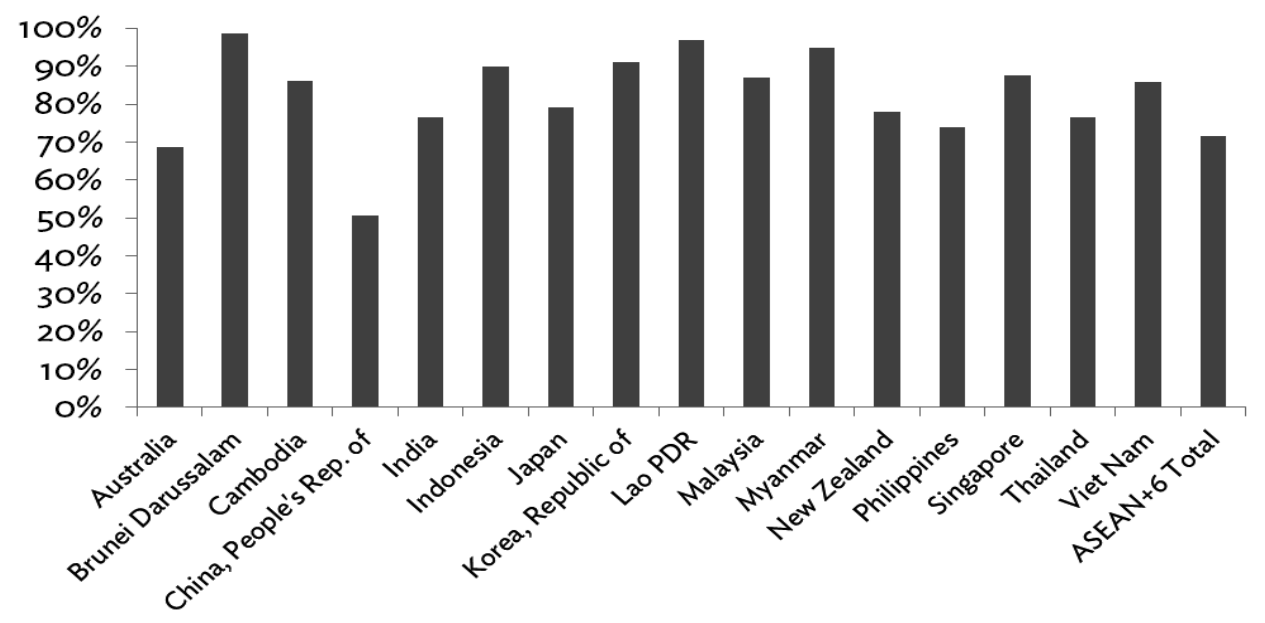

Lao PDR = Lao People's Democratic Republic.

Source: Author's computations based on IMF Direction of Trade Statistics (data downloaded May 2013) and Menon (2014). 


\section{Table 2: Value of Goods Imports from FTA Partners ( $\$$ million) and Share in Total Imports (\%), 2011}

\begin{tabular}{|c|c|c|c|c|}
\hline Economy & Proposed & $\begin{array}{l}\text { FA Signed, Under Negotiation, } \\
\text { or Signed but not yet in Effect }\end{array}$ & Ratified & $\begin{array}{r}\text { Total Imports } \\
\text { from FTA partners }\end{array}$ \\
\hline Australia & $\begin{array}{r}2,073.5 \\
0.8 \%\end{array}$ & $\begin{array}{r}85,313.3 \\
32.8 \%\end{array}$ & $\begin{array}{r}91,051.7 \\
35.0 \%\end{array}$ & $\begin{array}{r}178,438.5 \\
68.6 \%\end{array}$ \\
\hline Brunei Darussalam & $0.0 \%$ & $\begin{array}{r}1,051.8 \\
16.4 \%\end{array}$ & $\begin{array}{r}5,267.9 \\
82.3 \%\end{array}$ & $\begin{array}{r}6,319.7 \\
98.7 \%\end{array}$ \\
\hline Cambodia & $\begin{array}{r}19.4 \\
0.2 \%\end{array}$ & $\begin{array}{r}285.9 \\
2.3 \%\end{array}$ & $\begin{array}{r}10,568.0 \\
83.7 \%\end{array}$ & $\begin{array}{r}10,873.3 \\
86.1 \%\end{array}$ \\
\hline $\begin{array}{l}\text { People's Republic } \\
\text { of China }\end{array}$ & $\begin{array}{r}61,403.0 \\
3.5 \%\end{array}$ & $\begin{array}{r}393,988.8 \\
22.6 \%\end{array}$ & $\begin{array}{r}428,091.6 \\
24.6 \%\end{array}$ & $\begin{array}{r}883,483.4 \\
50.7 \%\end{array}$ \\
\hline India & $\begin{array}{r}11,643.6 \\
2.5 \%\end{array}$ & $\begin{array}{r}215,069.2 \\
46.2 \%\end{array}$ & $\begin{array}{r}128,698.3 \\
27.7 \%\end{array}$ & $\begin{array}{r}355,411.1 \\
76.4 \%\end{array}$ \\
\hline Indonesia & $\begin{array}{r}11,206.3 \\
6.3 \%\end{array}$ & $\begin{array}{r}28,483.0 \\
16.1 \%\end{array}$ & $\begin{array}{r}119,985.7 \\
67.6 \%\end{array}$ & $\begin{array}{r}159,675.0 \\
90.0 \%\end{array}$ \\
\hline Japan & $\begin{array}{r}516.3 \\
0.1 \%\end{array}$ & $\begin{array}{r}520,084.7 \\
60.8 \%\end{array}$ & $\begin{array}{r}155,639.9 \\
18.2 \%\end{array}$ & $\begin{array}{r}676,240.9 \\
79.1 \%\end{array}$ \\
\hline Republic of Korea & $\begin{array}{r}23,301.3 \\
4.4 \%\end{array}$ & $\begin{array}{r}261,776.9 \\
49.9 \%\end{array}$ & $\begin{array}{r}191,875.3 \\
36.6 \%\end{array}$ & $\begin{array}{r}476,953.5 \\
90.9 \%\end{array}$ \\
\hline $\begin{array}{l}\text { Lao People's } \\
\text { Democratic Republic }\end{array}$ & $\begin{array}{r}0.3 \\
0.0 \%\end{array}$ & $\begin{array}{r}292.5 \\
6.3 \%\end{array}$ & $\begin{array}{r}4,198.5 \\
90.6 \%\end{array}$ & $\begin{array}{r}4,491.2 \\
96.9 \%\end{array}$ \\
\hline Malaysia & $\begin{array}{r}8,199.9 \\
4.4 \%\end{array}$ & $\begin{array}{r}40,083.8 \\
21.4 \%\end{array}$ & $\begin{array}{r}114,938.2 \\
61.3 \%\end{array}$ & $\begin{array}{r}163,222.0 \\
87.0 \%\end{array}$ \\
\hline Myanmar & $\begin{array}{r}8.8 \\
0.1 \%\end{array}$ & $\begin{array}{r}206.7 \\
1.5 \%\end{array}$ & $\begin{array}{r}12,756.1 \\
93.2 \%\end{array}$ & $\begin{array}{r}12,971.6 \\
94.8 \%\end{array}$ \\
\hline New Zealand & $\begin{array}{l}176.3 \\
0.5 \%\end{array}$ & $\begin{array}{r}11,247.1 \\
30.6 \%\end{array}$ & $\begin{array}{r}17,244.7 \\
47.0 \%\end{array}$ & $\begin{array}{r}28,668.0 \\
78.1 \%\end{array}$ \\
\hline Philippines & $\begin{array}{r}6,586.1 \\
10.9 \%\end{array}$ & $\begin{array}{r}4,447.1 \\
7.4 \%\end{array}$ & $\begin{array}{r}33,452.5 \\
55.6 \%\end{array}$ & $\begin{array}{r}44,485.7 \\
74.0 \%\end{array}$ \\
\hline Singapore & $\begin{array}{l}141.6 \\
0.0 \%\end{array}$ & $\begin{array}{r}92,555.1 \\
25.3 \%\end{array}$ & $\begin{array}{r}228,260.1 \\
62.4 \%\end{array}$ & $\begin{array}{r}320,956.8 \\
87.7 \%\end{array}$ \\
\hline Thailand & $\begin{array}{r}3,061.9 \\
1.3 \%\end{array}$ & $\begin{array}{r}41,233.9 \\
18.0 \%\end{array}$ & $\begin{array}{r}131,155.0 \\
57.2 \%\end{array}$ & $\begin{array}{r}175,450.9 \\
76.6 \%\end{array}$ \\
\hline Viet Nam & $\begin{array}{r}1,061.7 \\
1.0 \%\end{array}$ & $\begin{array}{r}14,638.9 \\
14.0 \%\end{array}$ & $\begin{array}{r}73,933.8 \\
70.7 \%\end{array}$ & $\begin{array}{r}89,634.4 \\
85.8 \%\end{array}$ \\
\hline ASEAN+6 Total & $\begin{array}{r}129,400.1 \\
2.6 \%\end{array}$ & $\begin{array}{r}1,710,758.8 \\
34.2 \%\end{array}$ & $\begin{array}{r}1,747,117.4 \\
34.9 \%\end{array}$ & $\begin{array}{r}3,587,276.3 \\
71.6 \%\end{array}$ \\
\hline
\end{tabular}

Source: Author's computations based on IMF Direction of Trade Statistics (data downloaded May 2013) and Menon (2014). 
But this is already happening. Apart from Europe, utilization rates of preferences are generally low, particularly in Asia. As a result, the trade-weighted preference margin for intra-ASEAN trade in 2008 , for instance, was a mere $2.3 \%$, while $72.9 \%$ of trade traveled at a zero MFN rate, according to the WTO (2011). Globally, only about $15 \%$ of trade flows are conducted under preferential terms, while the costs of trying to implement largely unused preferential arrangements continue to increase. The fact that preference utilization rates are generally less than complete needs to be taken into account in quantifying the impacts of FTAs, and in assessing the relative merits of pursuing nonreciprocal modalities of liberalization such as the multilateralization of preferences. Previous studies on the impacts of FTAs in East Asia, for instance, have assumed full utilization of preferences. The evidence suggests that this assumption is seriously in error, with the estimated uptake particularly low in this region. In assessing the impact of tariff liberalization in the case of RCEP, our regional puzzle example, Menon (2014C) assumes a more realistic utilization rate of $25 \%$ and then compares impacts under various scenarios. These scenarios include solving the regional puzzle (RCEP) with complete (Scenario 1, or S1) and incomplete (25\%) utilization (S2); multilateralization of preferences by RCEP members ( $\left.\mathrm{S}_{3}\right)$; an attempt at moving toward solving the global puzzle by linking RCEP with a rest-of-the-world (ROW) FTA, but again with complete ( $\mathrm{S}_{4}$ ) and incomplete $\left(\mathrm{S}_{5}\right)$ utilization, and finally a global free trade scenario (S6), which could be achieved by successfully solving the global puzzle or by all countries pursuing multilateralization of preferences.

Table 3 compares preferential liberalization with multilateralization of preferences and we find that the latter is superior in all cases, and especially when incomplete utilization is taken into account. We find that actual utilization rates significantly diminish the benefits from preferential liberalization, but in a nonlinear way. In general, when members extend their preferential reductions to nonmembers on a non-discriminatory basis, welfare is enhanced because of three primary effects: (i) the extent of the liberalization is greater, (ii) the broader liberalization undoes the welfare-reducing trade diversion resulting from the preferential liberalization, and (iii) the productivity of scarce resources within each member country is allocated more efficiently across its industries.

$\mathrm{S}_{4}$ and $\mathrm{S}_{5}$ are akin to cross-regional tie-ups of FTAs, whereby the ROW grouping reciprocates by reducing its tariffs on exports from ASEAN +6 . As noted, this would be a stylized example of how we could go about solving the global jigsaw puzzle. The benefits to members when reciprocity is introduced are greater than $S_{3}$ only when there is full utilization of preferences (S4). If utilization is incomplete ( $\left.\mathrm{S}_{5}\right)$, then members benefit more from multilateralization of preferences $\left(\mathrm{S}_{3}\right)$. However, the gross national product (GNP) of ROW falls by $0.15 \%$ under $\mathrm{S}_{4}$ (with much smaller declines under $\mathrm{S}_{5}$ ). These are the largest reductions for nonmembers under any of the scenarios. The additional gains to members, with full utilization of preferences (S4), appear to occur at the expense of nonmembers. This raises the potential for possible retaliatory actions by nonmembers, reducing the benefits to the world as a whole. If the maximum gains to members accrue at the expense of potential retaliatory actions, then the possibility of trade deflection raises the likelihood of low utilization rates. Since tariffs between large trading blocs such as NAFTA and the EU, and other significant groupings such as South America and Africa, remain unchanged, there are significant opportunities, and benefits, from trying to deflect trade in order to obtain duty-free access. 
From Spaghetti Bowl to J igsaw Puzzle? Addressing the Disarray in the W orld Trade System | 13

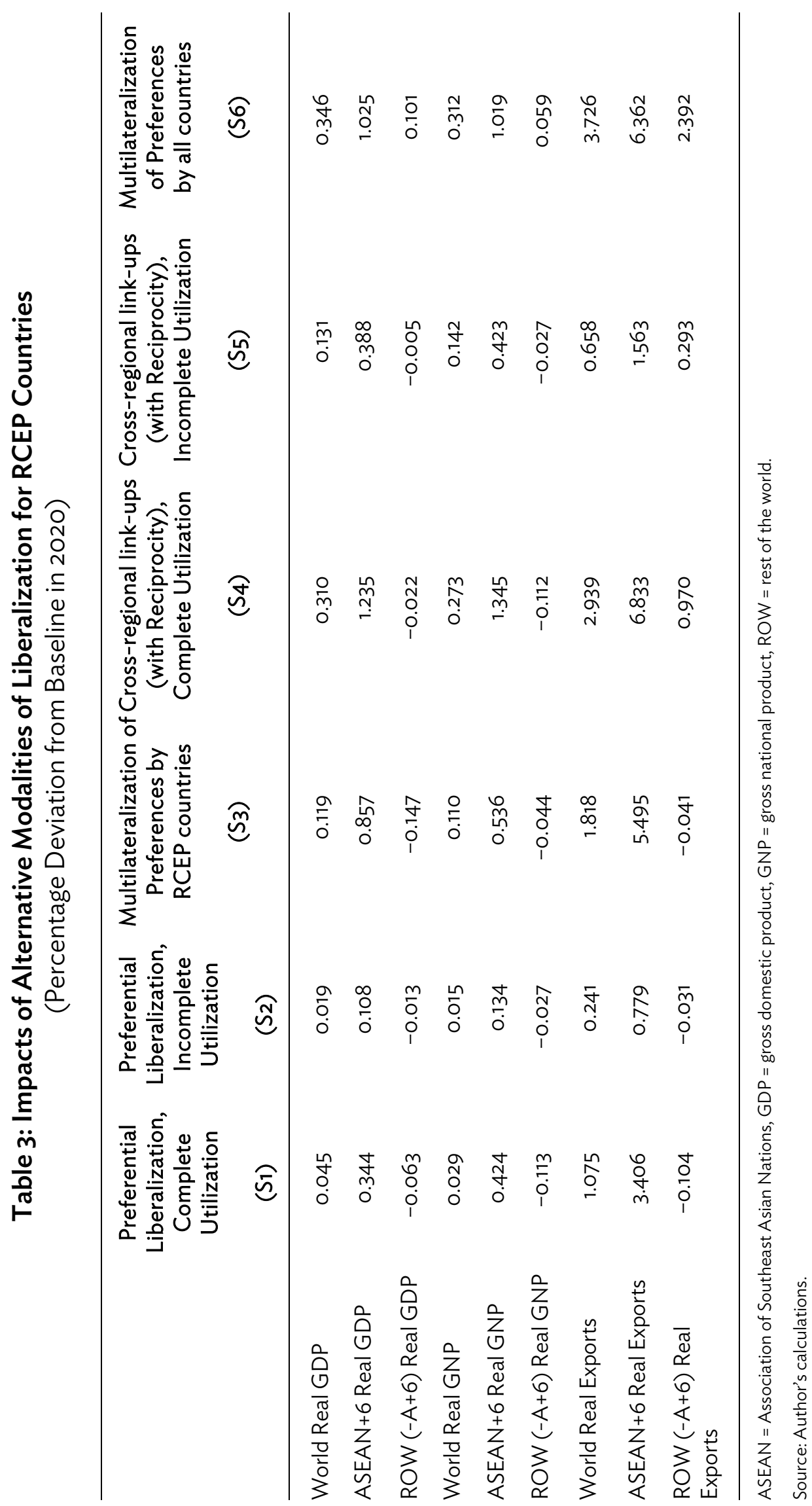


14 | Working Paper Series on Regional Economic Integration No. 140

In the final scenario of global liberalization, which is most likely to be achieved by all countries pursuing multilateralization of preferences, the GNP of all member countries would be increased. For RCEP members, there is little difference to the welfare effects of global liberalization (S6) versus multilateralization of preferences $\left(S_{3}\right)$. This finding has important implications for policy. It suggests that it is very much within the control of member countries to initiate actions that will produce the almost best welfare outcomes from trade liberalization. There is really no need to wait for an unlikely global liberalization solution for members to reap the benefits from it. It also appears that there is little to be gained from reciprocity, given time delays, negotiating costs, and uncertainty in the magnitude of benefits if utilization is incomplete.

Surely multilateralization deserves more serious consideration than ever before, and should no longer be dismissed as "pie in the sky." After all, this kind of unilateral action had accounted for more than two-thirds of all trade liberalization by developing countries in the 2 decades leading up to 2003 (World Bank 2005). There is also a host of other evidence, ${ }^{4}$ including that of Vezina (2010), which shows that it was unilateral actions which played an overwhelming role in trade liberalization of the original ASEAN members, and in drawing in foreign direct investment (FDI) to these countries to supplant the regional supply chain. In this way, the rise in regionalism may eventually be the most compelling factor in contributing to its own demise by revitalizing multilateralization, if not the multilateral system. As Hill and Menon (2008) put it, the proliferation of bilateral and plurilateral FTAs may eventually lead to them collapsing under their own weight.

While the application of the multilateralization approach is relatively straightforward when it comes to tariffs and other similar technical barriers, it is also an approach naturally suited to nontariff barriers (NTBs) and difficult sectors such as services. Although bilateral or regional negotiations can play a role in having an NTB removed, once they are removed, it may be difficult or costly to exclude third parties from participating or sharing in the benefits. The removal of many NTBs share public good characteristics in that they are non-excludable and nonrival in consumption; that is, once they are provided (this provision may involve removing a constraint), then it is difficult, if not impossible, to avoid free-riding. Unlike tariffs, it is either costly, often prohibitively so, or impractical to remove NTBs in an exclusive or preferential manner. Similarly, if services liberalization is pursued through harmonization of standards rather than MRAs, nonmembers can easily accede. In either case, the possibility of multilateralizing harmonized rules and regulations or mutually recognized requirements is present, although it is more easily done with the former than with the latter

4. For more examples, ranging from Australia and New Zealand to India and Central Europe, refer to the two volume publication edited by Jagdish Bhagwati (2002), and summarized in the Introduction. 


\section{Conclusion}

The rise of mega-regionals - such as RCEP, the TPP, and theT-TIP-suggests that the world trade system is more like a jigsaw puzzle than a spaghetti bowl these days. There are both regional and global jigsaw puzzles to be solved-and in that order-if order is to return to a fragmented world trade system. But both the regional and global puzzles may remain just that, given the difficulties associated with resolving the problems at each level. The difficulties of FTA consolidation at the regional level have been widely documented, while piecing together the blocs around the world to form a coherent whole is even more challenging, and has never been attempted. In this context, a way forward is to return to the most widely used modality of trade liberalization-unilateral actions-but this time involving the multilateralization of preferences rather than unreciprocated reductions in tariff rates. As more and more FTAs are negotiated, preference erosion sets in, reducing the resistance of FTA partners to multilateralization. Its application to tariffs and other technical barriers is straightforward, but it is also an approach naturally suited to NTBs and difficult sectors such as services. The removal of many NTBs share public good characteristics that make it either costly or impractical to be discriminatory or exclusive. Similarly, if services liberalization is pursued through harmonization of standards or MRAs, the possibility of multilateralization exists. If harmonization is achieved through regulatory convergence, for instance, rather than through MRAs, it will facilitate multilateralization because it will be easier for nonmembers to accede. Therefore, multilateralization of preferences, whether tariff or nontariff, appears to present a practical way forward in addressing the disarray in the world trade system. 
16 | Working Paper Series on Regional Economic Integration No. 140

\section{References}

R. Baldwin. 2004. The Spoke Trap: Hub and Spoke Bilateralism in East Asia. Working Paper 402. Seoul: Korea Institute of Economic Policy.

R. Baldwin. 2006. Multilateralising Regionalism: Spaghetti Bowls as Building Blocs on the Path to Global Free Trade. World Economy. pp. 1451-1518.

J. Bhagwati. 1991.The World Trading System at Risk. Princeton: Princeton University Press.

J. Bhagwati. 2002. Introduction: The Unilateral Freeing of Trade Versus Reciprocity in J. Bhagwati (ed.) Going Alone: The Case for Relaxed Reciprocity in Freeing Trade. Cambridge, Massachusetts: MIT Press. Available at http://www.colombia.edu/ jb38/papers/pdf/ Going_Alone_Final.pdf

J. Bhagwati. 2008.Termites in the Trading System. New York: Oxford University Press.

S.B. Das. 2012. Asia's Regional Comprehensive Economic Partnership. East Asia Forum. Available at http://www.eastasiaforum.org/2012/08/27/asias-regional-comprehensiveeconomic-partnership/

H. Hill. 1994. Australia's Asia-Pacific Connections. Economics Division Working Papers No. EA 94/2. Research School of Pacific and Asian Studies. Australian National University: Canberra.

H. Hill and J. Menon. 2008. Back to Basics on Asian Trade. Far Eastern Economic Review. 171 (5). pp. 44-47.

H. Hill and J. Menon. 2012. ASEAN Economic Integration: Driven by Markets, Bureaucrats, or Both? in M.E. Kreinin and M.G. Plummer (eds.) The Oxford Handbook of International Commercial Policy. Oxford: Oxford University Press. pp. 357-386.

M. Kawai and G. Wignaraja. 2013. Addressing the Challenges of Asian FTAs. East Asia Forum. Available at http://www.eastasiaforum.org/2013/06/10/addressing-policy-challengesof-asian-ftas/

E. Medalla. 2011. Taking Stock of the ROOs in the ASEAN+1 FTAs: Toward Deepening East Asian Integration. Discussion Paper Series No. 2011-36. Manila: Philippine Institute of Development Studies.

J. Menon. 2012. Supporting the Growth or Spread of International Production Networks in Asia: How Can Trade Policy Help? ADB Working Papers in Regional Economic Integration No. 112. Manila: ADB. Available at http://www.adb.org/publications/supporting-growthand-spread-international-production-networks-asia-how-can-trade-policy-help 
J. Menon. 2013. The Challenge Facing Asia's Regional Comprehensive Economic Partnership. East Asia Forum. 23 June. Available at http://www.eastasiaforum.org/2013/o6/23/thechallenge-facing-asias-regional-comprehensive-economic-partnership/

J. Menon. 2014a. A Way out of Preferential Deals. Presentation to the OECD Global Forum on Trade 2014. 11-12 February. Paris: OECD. Available at http://www.oecd.org/tad/events/ OECD-gft-2014-way-out-preferential-deals-menon-presentation.pdf

J. Menon. 2014b. Mega-regional trade deals and the global mega-mess. VoxEU, 9 June. Available at http://www.voxeu.org/article/mega-regional-trade-deals-and-globalmega-mess

J. Menon. 2014C. Multilateralization of Preferences versus Reciprocity when FTAs are Underutilized, The World Economy, forthcoming. Available at http://aric.adb.org/pdf/ workingpaper/WP109_Menon_Preferential_vs_Non-Preferential.pdf

J. Menon and A.C. Melendez. 2011. Trade and Investment in the Greater Mekong Subregion: Remaining Challenges and the Unfinished Policy Agenda, ADB Working Paper Series on Regional Economic Integration. No. 78. Manila: ADB. Available at http://www.aric.adb. org/pdf/workingpaper/WP78_Menon_Melendez_Trade_and_Investment_in_the_G MS.pdf

P.L. Vézina. 2010. Race-To-The-Bottom Tariff Cutting. IHEID Working Paper. No. 12. Geneva: IHEID.

D. Weerakoon. 2008. India's Role in SAARC: Integration and the Way Ahead. Paper presented to the ADB-ICREAR Workshop on South Asian Integration. March. New Delhi.

World Bank. 2005.Global Economic Prospects 2005: Trade, Regionalism, and Development. Washington, DC: World Bank.

WTO. 2011.World Trade Report 2011. Geneva: WTO. 
18 | Working Paper Series on Regional Economic Integration No. 140

\section{ADB Working Paper Series on Regional Economic Integration}

1. "The ASEAN Economic Community and the European Experience" by Michael G. Plummer

2. "Economic Integration in East Asia: Trends, Prospects, and a Possible Roadmap" by Pradumna B. Rana

3. "Central Asia after Fifteen Years of Transition: Growth, Regional Cooperation, and Policy Choices" by Malcolm Dowling and Ganeshan Wignaraja

4. "Global Imbalances and the Asian Economies: Implications for Regional Cooperation" by Barry Eichengreen

5. "Toward Win-Win Regionalism in Asia: Issues and Challenges in Forming Efficient Trade Agreements" by Michael G. Plummer

6. "Liberalizing Cross-Border Capital Flows: How Effective Are Institutional Arrangements against Crisis in Southeast Asia" by Alfred Steinherr, Alessandro Cisotta, Erik Klär, and Kenan Šehović

7. "Managing the Noodle Bowl: The Fragility of East Asian Regionalism" by Richard E. Baldwin

8. "Measuring Regional Market Integration in Developing Asia: A Dynamic Factor Error Correction Model (DF-ECM) Approach" by Duo Qin, Marie Anne Cagas, Geoffrey Ducanes, Nedelyn Magtibay-Ramos, and Pilipinas F. Quising

9. "The Post-Crisis Sequencing of Economic Integration in Asia: Trade as a Complement to a Monetary Future" by Michael G. Plummer and Ganeshan Wignaraja

10. "Trade Intensity and Business Cycle Synchronization: The Case of East Asia” by Pradumna B. Rana

11. "Inequality and Growth Revisited" by Robert J. Barro

12. "Securitization in East Asia" by Paul Lejot, Douglas Arner, and Lotte SchouZibell

13. "Patterns and Determinants of Cross-border Financial Asset Holdings in East Asia" by Jong-Wha Lee

14. "Regionalism as an Engine of Multilateralism: A Case for a Single East Asian FTA" by Masahiro Kawai and Ganeshan Wignaraja 
15. "The Impact of Capital Inflows on Emerging East Asian Economies: Is Too Much Money Chasing Too Little Good?" by Soyoung Kim and Doo Yong Yang

16. "Emerging East Asian Banking Systems Ten Years after the 1997-1998 Crisis" by Charles Adams

17. "Real and Financial Integration in East Asia" by Soyoung Kim and JongWha Lee

18. "Global Financial Turmoil: Impact and Challenges for Asia's Financial Systems" by Jong-Wha Lee and Cyn-Young Park

19. "Cambodia's Persistent Dollarization: Causes and Policy Options" by Jayant Menon

20. "Welfare Implications of International Financial Integration" by Jong-Wha Lee and Kwanho Shin

21. "Is the ASEAN-Korea Free Trade Area (AKFTA) an Optimal Free Trade Area?" by Donghyun Park, Innwon Park, and Gemma Esther B. Estrada

22. "India's Bond Market-Developments and Challenges Ahead" by Stephen Wells and Lotte Schou- Zibell

23. "Commodity Prices and Monetary Policy in Emerging East Asia" by Hsiao Chink Tang

24. "Does Trade Integration Contribute to Peace?" by Jong-Wha Lee and Ju Hyun Pyun

25. "Aging in Asia: Trends, Impacts, and Responses" by Jayant Menon and Anna Melendez-Nakamura

26. "Re-considering Asian Financial Regionalism in the 1990s" by Shintaro Hamanaka

27. "Managing Success in Viet Nam: Macroeconomic Consequences of Large Capital Inflows with Limited Policy Tools" by Jayant Menon

28. "The Building Block versus Stumbling Block Debate of Regionalism: From the Perspective of Service Trade Liberalization in Asia" by Shintaro Hamanaka

29. "East Asian and European Economic Integration: A Comparative Analysis" by Giovanni Capannelli and Carlo Filippini 
30. "Promoting Trade and Investment in India's Northeastern Region" by M. Govinda Rao

31. "Emerging Asia: Decoupling or Recoupling" by Soyoung Kim, Jong-Wha Lee, and Cyn-Young Park

32. "India's Role in South Asia Trade and Investment Integration" by Rajiv Kumar and Manjeeta Singh

33. "Developing Indicators for Regional Economic Integration and Cooperation" by Giovanni Capannelli, Jong-Wha Lee, and Peter Petri

34. "Beyond the Crisis: Financial Regulatory Reform in Emerging Asia" by Chee Sung Lee and Cyn-Young Park

35. "Regional Economic Impacts of Cross-Border Infrastructure: A General Equilibrium Application to Thailand and Lao People's Democratic Republic" by Peter Warr, Jayant Menon, and Arief Anshory Yusuf

36. "Exchange Rate Regimes in the Asia-Pacific Region and the Global Financial Crisis" by Warwick J. McKibbin and Waranya Pim Chanthapun

37. "Roads for Asian Integration: Measuring ADB's Contribution to the Asian Highway Network” by Srinivasa Madhur, Ganeshan Wignaraja, and Peter Darjes

38. "The Financial Crisis and Money Markets in Emerging Asia" by Robert Rigg and Lotte Schou-Zibell

39. "Complements or Substitutes? Preferential and Multilateral Trade Liberalization at the Sectoral Level" by Mitsuyo Ando, Antoni Estevadeordal, and Christian Volpe Martincus

40. "Regulatory Reforms for Improving the Business Environment in Selected Asian Economies-How Monitoring and Comparative Benchmarking can Provide Incentive for Reform" by Lotte Schou-Zibell and Srinivasa Madhur

41. "Global Production Sharing, Trade Patterns, and Determinants of Trade Flows in East Asia" by Prema-chandra Athukorala and Jayant Menon

42. "Regionalism Cycle in Asia (-Pacific): A Game Theory Approach to the Rise and Fall of Asian Regional Institutions" by Shintaro Hamanaka

43. "A Macroprudential Framework for Monitoring and Examining Financial Soundness" by Lotte Schou-Zibell, Jose Ramon Albert, and Lei Lei Song 
44. "A Macroprudential Framework for the Early Detection of Banking Problems in Emerging Economies" by Claudio Loser, Miguel Kiguel, and David Mermelstein

45. "The 2008 Financial Crisis and Potential Output in Asia: Impact and Policy Implications" by Cyn-Young Park, Ruperto Majuca, and Josef Yap

46. "Do Hub-and-Spoke Free Trade Agreements Increase Trade? A Panel Data Analysis" by Jung Hur, Joseph Alba, and Donghyun Park

47. "Does a Leapfrogging Growth Strategy Raise Growth Rate? Some International Evidence" by Zhi Wang, Shang-Jin Wei, and Anna Wong

48. "Crises in Asia: Recovery and Policy Responses" by Kiseok Hong and Hsiao Chink Tang

49. “A New Multi-Dimensional Framework for Analyzing Regional Integration: Regional Integration Evaluation (RIE) Methodology" by Donghyun Park and Mario Arturo Ruiz Estrada

50. "Regional Surveillance for East Asia: How Can It Be Designed to Complement Global Surveillance?" by Shinji Takagi

51. "Poverty Impacts of Government Expenditure from Natural Resource Revenues" by Peter Warr, Jayant Menon, and Arief Anshory Yusuf

52. "Methods for Ex Ante Economic Evaluation of Free Trade Agreements" by David Cheong

53. "The Role of Membership Rules in Regional Organizations" by Judith Kelley

54. "The Political Economy of Regional Cooperation in South Asia" by V.V. Desai

55. “Trade Facilitation Measures under Free Trade Agreements: Are They Discriminatory against Non-Members?" by Shintaro Hamanaka, Aiken Tafgar, and Dorothea Lazaro

56. "Production Networks and Trade Patterns in East Asia: Regionalization or Globalization?" by Prema-chandra Athukorala

57. "Global Financial Regulatory Reforms: Implications for Developing Asia" by Douglas W. Arner and Cyn-Young Park

58. "Asia's Contribution to Global Rebalancing” by Charles Adams, Hoe Yun Jeong, and Cyn-Young Park 
22 | Working Paper Series on Regional Economic Integration No. 140

59. "Methods for Ex Post Economic Evaluation of Free Trade Agreements" by David Cheong

6o. "Responding to the Global Financial and Economic Crisis: Meeting the Challenges in Asia" by Douglas W. Arner and Lotte Schou-Zibell

61. "Shaping New Regionalism in the Pacific Islands: Back to the Future?" by Satish Chand

62. "Organizing the Wider East Asia Region" by Christopher M. Dent

63. "Labour and Grassroots Civic Interests In Regional Institutions" by Helen E.S. Nesadurai

64. "Institutional Design of Regional Integration: Balancing Delegation and Representation" by Simon Hix

65. "Regional Judicial Institutions and Economic Cooperation: Lessons for Asia?" by Erik Voeten

66. "The Awakening Chinese Economy: Macro and Terms of Trade Impacts on 10 Major Asia-Pacific Countries" by Yin Hua Mai, Philip Adams, Peter Dixon, and Jayant Menon

67. "Institutional Parameters of a Region-Wide Economic Agreement in Asia: Examination of Trans-Pacific Partnership and ASEAN $+\alpha$ Free Trade Agreement Approaches" by Shintaro Hamanaka

68. "Evolving Asian Power Balances and Alternate Conceptions for Building Regional Institutions" by Yong Wang

69. "ASEAN Economic Integration: Features, Fulfillments, Failures, and the Future" by Hal Hill and Jayant Menon

70. "Changing Impact of Fiscal Policy on Selected ASEAN Countries" by Hsiao Chink Tang, Philip Liu, and Eddie C. Cheung

71. "The Organizational Architecture of the Asia-Pacific: Insights from the New Institutionalism" by Stephan Haggard

72. "The Impact of Monetary Policy on Financial Markets in Small Open Economies: More or Less Effective During the Global Financial Crisis?" by Steven Pennings, Arief Ramayandi, and Hsiao Chink Tang

73. "What do Asian Countries Want the Seat at the High Table for? G20 as a New Global Economic Governance Forum and the Role of Asia" by Yoon Je Cho 
74. “Asia's Strategic Participation in the Group of 20 for Global Economic Governance Reform: From the Perspective of International Trade" by Taeho Bark and Moonsung Kang

75. “ASEAN's Free Trade Agreements with the People's Republic of China, Japan, and the Republic of Korea: A Qualitative and Quantitative Analysis" by Gemma Estrada, Donghyun Park, Innwon Park, and Soonchan Park

76. "ASEAN-5 Macroeconomic Forecasting Using a GVAR Model" by Fei Han and Thiam Hee $\mathrm{Ng}$

77. "Early Warning Systems in the Republic of Korea: Experiences, Lessons, and Future Steps" by Hyungmin Jung and Hoe Yun Jeong

78. "Trade and Investment in the Greater Mekong Subregion: Remaining Challenges and the Unfinished Policy Agenda" by Jayant Menon and Anna Cassandra Melendez

79. "Financial Integration in Emerging Asia: Challenges and Prospects" by Cyn-Young Park and Jong-Wha Lee

80. "Sequencing Regionalism: Theory, European Practice, and Lessons for Asia" by Richard E. Baldwin

81. "Economic Crises and Institutions for Regional Economic Cooperation" by C. Randall Henning

82. "Asian Regional Institutions and the Possibilities for Socializing the Behavior of States" by Amitav Acharya

83. "The People's Republic of China and India: Commercial Policies in the Giants" by Ganeshan Wignaraja

84. "What Drives Different Types of Capital Flows and Their Volatilities?" by Rogelio Mercado and Cyn-Young Park

85. “Institution Building for African Regionalism” by Gilbert M. Khadiagala

86. "Impediments to Growth of the Garment and Food Industries in Cambodia: Exploring Potential Benefits of the ASEAN-PRC FTA" by Vannarith Chheang and Shintaro Hamanaka

87. "The Role of the People's Republic of China in International Fragmentation and Production Networks: An Empirical Investigation" by Hyun-Hoon Lee, Donghyun Park, and Jing Wang 
24 | Working Paper Series on Regional Economic Integration No. 140

88. "Utilizing the Multiple Mirror Technique to Assess the Quality of Cambodian Trade Statistics" by Shintaro Hamanaka

89. "Is Technical Assistance under Free Trade Agreements WTO-Plus?" A Review of Japan-ASEAN Economic Partnership Agreements" by Shintaro Hamanaka

90. "Intra-Asia Exchange Rate Volatility and Intra-Asia Trade: Evidence by Type of Goods" by Hsiao Chink Tang

91. "Is Trade in Asia Really Integrating?" by Shintaro Hamanaka

92. "The PRC's Free Trade Agreements with ASEAN, Japan, and the Republic of Korea: A Comparative Analysis" by Gemma Estrada, Donghyun Park, Innwon Park, and Soonchan Park

93. "Assessing the Resilience of ASEAN Banking Systems: The Case of the Philippines" by Jose Ramon Albert and Thiam Hee Ng

94. "Strengthening the Financial System and Mobilizing Savings to Support More Balanced Growth in ASEAN+3" by A. Noy Siackhachanh

95. "Measuring Commodity-Level Trade Costs in Asia: The Basis for Effective Trade Facilitation Policies in the Region" by Shintaro Hamanaka and Romana Domingo

96. "Why do Imports Fall More than Exports Especially During Crises? Evidence from Selected Asian Economies" by Hsiao Chink Tang

97. "Determinants of Local Currency Bonds and Foreign Holdings: Implications for Bond Market Development in the People's Republic of China" by Kee-Hong Bae

98. "ASEAN-China Free Trade Area and the Competitiveness of Local Industries: A Case Study of Major Industries in the Lao People's Democratic Republic" by Leebeer Leebouapao, Sthabandith Insisienmay, and Vanthana Nolintha

99. "The Impact of ACFTA on People's Republic of China-ASEAN Trade: Estimates Based on an Extended Gravity Model for Component Trade" by Yu Sheng, Hsiao Chink Tang, and Xinpeng Xu

100. "Narrowing the Development Divide in ASEAN: The Role of Policy" by Jayant Menon 
101. "Different Types of Firms, Products, and Directions of Trade: The Case of the People's Republic of China" by Hyun-Hoon Lee, Donghyun Park, and Jing Wang

102. "Anatomy of South-South FTAs in Asia: Comparisons with Africa, Latin America, and the Pacific Islands" by Shintaro Hamanaka

103. "Japan's Education Services Imports: Branch Campus or Subsidiary Campus?" by Shintaro Hamanaka

104. "A New Regime of SME Finance in Emerging Asia: Empowering GrowthOriented SMEs to Build Resilient National Economies" by Shigehiro Shinozaki

105. "Critical Review of East Asia - South America Trade" by Shintaro Hamanaka and Aiken Tafgar

106. "The Threat of Financial Contagion to Emerging Asia's Local Bond Markets: Spillovers from Global Crises" by Iwan J. Azis, Sabyasachi Mitra, Anthony Baluga, and Roselle Dime

107. "Hot Money Flows, Commodity Price Cycles, and Financial Repression in the US and the People's Republic of China: The Consequences of Near Zero US Interest Rates" by Ronald McKinnon and Zhao Liu

108. "Cross-Regional Comparison of Trade Integration: The Case of Services" by Shintaro Hamanaka

109. "Preferential and Non-Preferential Approaches to Trade Liberalization in East Asia: What Differences Do Utilization Rates and Reciprocity Make?" by Jayant Menon

110. "Can Global Value Chains Effectively Serve Regional Economic Development in Asia?" by Hans-Peter Brunner

111. "Exporting and Innovation: Theory and Firm-Level Evidence from the People's Republic of China" by Faqin Lin and Hsiao Chink Tang

112. "Supporting the Growth and Spread of International Production Networks in Asia: How Can Trade Policy Help?" by Jayant Menon

113. "On the Use of FTAs: A Review of Research Methodologies" by Shintaro Hamanaka

114. “The People's Republic of China's Financial Policy and Regional Cooperation in the Midst of Global Headwinds" by Iwan J. Azis 
26 | Working Paper Series on Regional Economic Integration No. 140

115. "The Role of International Trade in Employment Growth in Micro- and Small Enterprises: Evidence from Developing Asia” by Jens Krüger

116. "Impact of Euro Zone Financial Shocks on Southeast Asian Economies" by Jayant Menon and Thiam Hee Ng

117. "What is Economic Corridor Development and What Can It Achieve in Asia's Subregions?" by Hans-Peter Brunner

118. "The Financial Role of East Asian Economies in Global Imbalances: An Econometric Assessment of Developments after the Global Financial Crisis" by Hyun-Hoon Lee and Donghyun Park

119. "Learning by Exporting: Evidence from India" by Apoorva Gupta, Ila Patnaik, and Ajay Shah

120. "FDI Technology Spillovers and Spatial Diffusion in the People's Republic of China" by Mi Lin and Yum K. Kwan

121. "Capital Market Financing for SMEs: A Growing Need in Emerging Asia" by Shigehiro Shinozaki

122. "Terms of Trade, Foreign Direct Investment, and Development: A Case of Intra-Asian Kicking Away the Ladder?" by Konstantin M. Wacker, Philipp Grosskurth, and Tabea Lakemann

123. "Can Low Interest Rates be Harmful: An Assessment of the Bank RiskTaking Channel in Asia" by Arief Ramayandi, Umang Rawat, and Hsiao Chink Tang

124. "Explaining Foreign Holdings of Asia's Debt Securities" by Charles Yuji Horioka, Takaaki Nomoto, and Akiko Terada-Hagiwara

125. "South Caucasus-People's Republic of China Bilateral Free Trade Agreements: Why It Matters" by Hasmik Hovhanesian and Heghine Manasyan

126. "Enlargement of Economic Framework in Southeast Asia and Trade Flows in Lao PDR" by Sithanonxay Suvannaphakdy, Hsiao Chink Tang, and Alisa DiCaprio

127. "The End of Grand Expectations: Monetary and Financial Integration After the Crisis in Europe" by Heribert Dieter

128. "The Investment Version of the Asian Noodle Bowl: The Proliferation of International Investment Agreements (IIAs)" by Julien Chaisse and Shintaro Hamanaka 
129. "Why Do Countries Enter into Preferential Agreements on Trade in Services?: Assessing the Potential for Negotiated Regulatory Convergence in Asian Services Markets" by Pierre Sauvé and Anirudh Shingal

130. "Analysis of Informal Obstacles to Cross-Border Economic Activity between Kazakhstan and Uzbekistan" by Roman Vakulchuk and Farrrukh Irnazarov

131. "The Nexus between Anti-Dumping Petitions and Exports during the Global Financial Crisis: Evidence on the People's Republic of China" by Faqin Lin, Hsiao Chink Tang, and Lin Wang

132. "Study of Non-Notified Trade Agreements to WTO: The Case of AsiaPacific" by Shintaro Hamanaka

133. "Equity Home Bias Financial Integration and Regulatory Reforms" by Cyn-Young Park and Rogelio V. Mercado, Jr.

134. "Financial Monitoring in New ASEAN 5 Countries" by Se Hee Lim and Noel G. Reyes

135. “Has Regional Integration Led to Greater Risk-Sharing in Asia?” by Thiam Hee Ng and Damaris Lee Yarcia

136. "How Capital Flows Affect Economy-Wide Vulnerability and Inequality: Flow-of-Funds Analysis of Selected Asian Economies" by Iwan J. Azis and Damaris Yarcia

137. "The Progress of Paperless Trade in Asia and the Pacific: Enabling International Supply Chain Integration" by Sung Heun Ha and Sang Won Lim

138. “World Trade Organization Agreement on Trade Facilitation: Assessing the Level of Ambition and Likely Impacts" by Shintaro Hamanaka

139. "Business Cycle Synchronization in Asia: The Role of Financial and Trade Linkages" by Yuwen Dai

\footnotetext{
*These papers can be downloaded from (ARIC) http://aric.adb.org/archives.php? section=o\&subsection=workingpapers or (ADB) http://www.adb.org/publications/series/ regional-economic-integration-working-papers
} 




\section{From Spaghetti Bowl to Jigsaw Puzzle?}

Addressing the Disarray in the World Trade System

The rise of mega-regionals suggests that the world trade system is fragmenting to the point it appears more like a jigsaw puzzle than a spaghetti bowl. There are both regional and global jigsaw puzzles to be solved-in that order-to rectify the situation but this appears impractical. Therefore, a way forward is to return to the most widely used modality of trade liberalizationunilateral actions - but this time involving the multilateralization of preferences.

\section{About the Asian Development Bank}

ADB's vision is an Asia and Pacific region free of poverty. Its mission is to help its developing member countries reduce poverty and improve the quality of life of their people. Despite the region's many successes, it remains home to approximately two-thirds of the world's poor: 1.6 billion people who live on less than $\$ 2$ a day, with 733 million struggling on less than $\$ 1.25$ a day. ADB is committed to reducing poverty through inclusive economic growth, environmentally sustainable growth, and regional integration.

Based in Manila, ADB is owned by 67 members, including 48 from the region. Its main instruments for helping its developing member countries are policy dialogue, loans, equity investments, guarantees, grants, and technical assistance.

\section{$\mathrm{ADB}$}

